\title{
Review \\ The Role of Cancer-Associated Fibroblasts in Cancer Invasion and Metastasis
}

\author{
Paris Jabeen Asif ${ }^{1,2,+}$ (D) Ciro Longobardi ${ }^{1,2,+}$, Michael Hahne ${ }^{3}$ and Jan Paul Medema ${ }^{1,2, *}$ \\ 1 Center for Experimental and Molecular Medicine, Cancer Center Amsterdam, Amsterdam UMC, \\ University of Amsterdam, 1105 AZ Amsterdam, The Netherlands; p.j.asif@amsterdamumc.nl (P.J.A.); \\ c.longobardi@amsterdamumc.nl (C.L.) \\ 2 Oncode Institute, Amsterdam UMC, University of Amsterdam, Meibergdreef 9, \\ 1105 AZ Amsterdam, The Netherlands \\ 3 Centre National de la Recherche Scientifique (CNRS), Institut de Génétique Moléculaire de Montpellier, \\ Université de Montpellier, 34090 Montpellier, France; michael.hahne@igmm.cnrs.fr \\ * Correspondence: j.p.medema@amsterdamumc.nl \\ + These authors contributed equally to this work.
}

Citation: Asif, P.J.; Longobardi, C.; Hahne, M.; Medema, J.P. The Role of Cancer-Associated Fibroblasts in Cancer Invasion and Metastasis. Cancers 2021, 13, 4720. https:/ / doi.org/10.3390/cancers13184720

Academic Editor: Debabrata Banerjee

Received: 3 August 2021

Accepted: 18 September 2021

Published: 21 September 2021

Publisher's Note: MDPI stays neutral with regard to jurisdictional claims in published maps and institutional affiliations.

Copyright: (C) 2021 by the authors. Licensee MDPI, Basel, Switzerland. This article is an open access article distributed under the terms and conditions of the Creative Commons Attribution (CC BY) license (https:/ / creativecommons.org/licenses/by/ $4.0 /)$.
Simple Summary: Cancer metastasis is often associated with a dismal prognosis for the patient. It is, therefore, crucial to understand the mechanisms behind the cascade of events that lead to metastatic disease. Cancer-associated fibroblasts (CAFs) play a key role in cancer progression. Therefore, it is of importance to understand the roles of CAFs in invasion, metastasis, and therapy resistance. Here, we reviewed the crosstalk between CAFs and tumor cells to summarize the current knowledge on CAF roles in cancers to provide the necessary structure to advance the field.

Abstract: Cancer-associated fibroblasts (CAFs) play a key role in cancer progression by contributing to extracellular matrix (ECM) deposition and remodeling, extensive crosstalk with cancer cells, epithelial-to-mesenchymal transition (EMT), invasion, metastasis, and therapy resistance. As metastasis is a main reason for cancer-related deaths, it is crucial to understand the role of CAFs in this process. Colorectal cancer (CRC) is a heterogeneous disease and lethality is especially common in a subtype of CRC with high stromal infiltration. A key component of stroma is cancer-associated fibroblasts (CAFs). To provide new perspectives for research on CAFs and CAF-targeted therapeutics, especially in CRC, we discuss the mechanisms, crosstalk, and functions involved in CAF-mediated cancer invasion, metastasis, and protection. This summary can serve as a framework for future studies elucidating these roles of CAFs.

Keywords: cancer-associated fibroblast; invasion; metastasis; colorectal cancer; extracellular matrix; epithelial-to-mesenchymal transition; CAF-targeted therapy

\section{Introduction}

The word "stroma" was derived from Greek and originally meant "covering" or "mattress", but, in 1835, it entered the field of biology as "a part of a tissue or organ with a structural or connective role". The stroma consists of many different cell types, but, in this review, we will focus on fibroblasts and their role in cancer invasion and metastasis.

Many articles describe a parallel dialogue between cancer-associated fibroblasts (CAFs) and tumor cells. This crosstalk enables cancer cells to attract fibroblasts and transform them into CAFs, and, in turn, these can modulate and protect cancer cells.

CAFs have been receiving a growing appreciation in the past few years. The impact of CAFs on cancer invasion and metastasis occurs through remodeling of the extracellular matrix (ECM), modulation of epithelial-to-mesenchymal transition (EMT) in cancer cells, secretion of growth factors supporting cancer cells, and influencing therapy responses. It is believed that this is mainly achieved by signaling between CAFs, cancer cells, and ECM exerted either by direct contact, secretion of cytokines, or extracellular vesicles (EVs). 
When cancers metastasize, this often is associated with a dismal prognosis for the patient. It is, therefore, crucial to understand the mechanisms behind the cascade of events that lead to metastatic disease. In this cascade, the extracellular matrix (ECM) plays an important role, as it provides structural and biochemical support to cells, but also restrains dispersion of cells. CAFs are known to modify the ECM during tumor progression, making it more permissive for tumor invasion into the surrounding tissue. Key secreted components for ECM remodeling are transforming growth factor beta (TGF- $\beta$ ), hepatocyte growth factor (HGF), and specific interleukins and metalloproteases. These factors aid tumor cells in invasion and metastasis and are interesting targets for therapy, which we will refer to as CAF-targeted therapy.

In this review, we summarize the literature highlighting the recent findings on the role of CAFs in invasion and metastasis to deduce the most promising mechanisms to target, and to find the most urgent remaining knowledge gaps.

\section{The Role of Fibroblasts in the Initiation of Invasion and Metastasis}

Plato and Aristotle used the Greek word "metastasis" to describe change by revolution of a political constitution [1]. In modern day society, the word metastasis is mostly related to cancer, with a meaning derived from Greek implying "rapid transition from one point to another". The metastatic cascade in cancers can be divided into five main processes: invasion, intravasation, circulation, extravasation, and colonization. CAFs can promote ECM remodeling in different ways: by secreting factors, enzymes, and miRNAs; by the generation of ECM tracks; and by inducing matrix stiffness (Figure 1) [2,3]. When we talk about CAFs, we usually refer to a highly heterogeneous population of cells with different functions. One of the ways to explain this heterogeneity could be the different origins that CAFs may have. Although the majority of CAFs appear to originate from tissue resident fibroblasts [4,5], recent research suggests that other origins of CAFs exist. It has been shown that bone-marrow-derived mesenchymal stromal cells could give rise to a subpopulation of CAFs that, in contrast to tissue resident fibroblasts, do not express platelet-derived growth factor receptor A (PDGFR $\alpha$ ) [6]. Another source of CAFs could be mature adipocytes [7], and even tumor cells after the process of EMT, which will be discussed later.

In recent years, the efforts of researchers have focused on understanding the differences between the various CAF subpopulations in various tumor types in order to derive clinical benefits. In pancreatic ductal adenocarcinoma (PDAC), two different CAF subtypes were identified with different intratumoral localization and different transcriptomic profiles. Myofibroblastic CAFs (myCAFs) have a direct interaction with neoplastic cells and high expression of alpha-smooth-muscle actin ( $\alpha \mathrm{SMA}$ ), while inflammatory CAFs (iCAFs) are located distally from the tumor cells and secrete high levels of IL-6 and some other cytokines [8]. Similarly, in breast cancer, Friedman et al. described two main subpopulations of CAFs: pCAFs and sCAFs, characterized by the expression of podoplanin (Pdnp) and S100A, respectively. The function and the composition of these CAFs change during tumor progression and the ratio between these populations is an indication of the clinical outcome [9]. In accordance with this, the phenotypes of CAFs change during mammary tumor progression [10]. In CRC, CAF-A and CAF-B were identified as two subtypes with different gene expressions [11]. As CAF subpopulations are being studied more extensively, the field is being updated frequently. These are only a few examples of works which try to shed light on the different CAFs in the TME, and recent reviews are available on the topic [12,13].

One of the big limitations of studying CAFs is the absence of markers that can be used to specifically identify all subpopulations. To overcome this problem, different markers, such as vimentin, $\alpha \mathrm{SMA}, \mathrm{PDGFR} \alpha / \beta$, and fibroblast activation protein $\alpha$ (FAP), are used in combination to identify all the different subpopulations of CAFs in the tumor [14].

In conclusion, further research needs to be conducted in order to define different CAF subpopulations in different tumor types and exploit this heterogeneity for clinical benefits. 

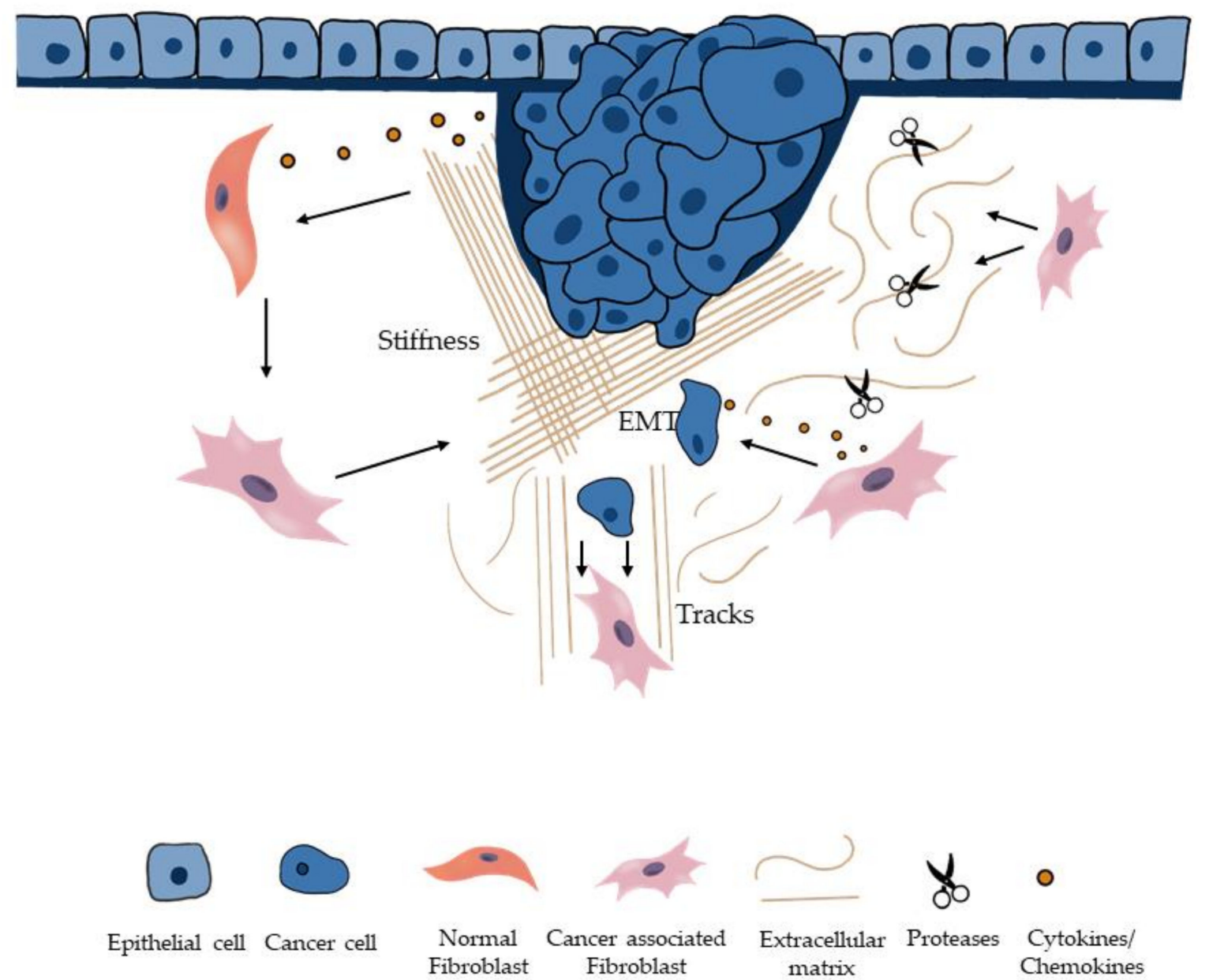

Figure 1. ECM remodeling and EMT modulated by CAFs. CAFs can modify ECM to promote invasion and metastasis of cancer cells by: inducing matrix stiffness; creating tracks for cancer cell invasion; secreting proteases and cytokines. CAFs can also induce EMT.

\subsection{CAFs and ECM Remodeling}

The ECM is a 3D scaffold that consists of around 300 unique macromolecules that provide mechanical structure and chemical cues for cellular and tissue organization. The ECM also binds factors related to growth, motility, survival, and angiogenesis, such as EGF, TGF- $\beta$, HGF, VEGF, and others. The core matrisome encompasses mainly collagens and glycoproteins and can be modified by secreted remodeling enzymes, such as oxidases and proteases [15]. Cells are anchored in this ECM, which provides a stabilizing structure and a framework that influences cell proliferation and survival, but also harbors other physiological and biochemical cues for the cells [16]. When cells receive incoming signals from the tiny ECM protrusions, called filopodia, the actin skeleton can be rearranged [16,17].

ECM modification is a physiological process that mostly occurs during development, tissue regeneration, and wound healing $[3,18]$. Remodeling mechanisms include deposition, modification, degradation, and organization, which are strictly regulated in normal conditions. Fibroblasts are the main producers of ECM components and ECM-remodeling enzymes that contribute to stromal homeostasis [3]. However, in cancer, these mechanisms are deregulated. Tumor growth and metastasis are highly dependent on the crosstalk between tumor cells and their microenvironment. Some of the main contributors of cancerrelated ECM remodeling are deregulated lysyl oxidases (LOXs), matrix metalloproteinases (MMPs), and transglutaminases (TGMs) [2,19,20]. For example, in CRC, MMPs have been shown to significantly change the ECM composition. Under physiological conditions 
MMPs are kept in check by MMP inhibitor TIMP-3, which directly binds and inactivates MMPs. The balance between TIMPs and MMPs is key for ECM stability, but, in CRC, MMP-2 and MMP-9 expression are increased, along with a downregulation of TIMP-3 and collagen type IV leading to degradation of ECM. These changes are favorable to cell proliferation, but, above all, also to invasion (Figure 1) [21].

As mentioned before, CAFs can facilitate invasion through the generation of tracks in the ECM by digesting the matrix and, thereby, allowing cancer cells to leave the site of origin (Figure 1) [5,22,23]. Force-mediated and protease-mediated matrix remodeling are required for the formation of these tracks. Particularly, Rho-ROCK and MMPs play a fundamental role for invasion of the cancer cells in this manner [24]. In accordance with this, Neri et al. demonstrated that podoplanin (PDPN)-expressing CAFs, can boost the invasion of cancer cells in lung adenocarcinoma through the activation of the Rho-ROCK pathway [25]. Inhibition of tracks could be a potential means of preventing invasion and, hence, metastasis.

\subsection{CAFs Can Induce Stiffness of ECM}

Matrix stiffness is defined as "the capacity of the matrix to resist deformation from an applied force" and is mainly dependent on ECM organization and composition [26]. Tumor ECM has been shown to be 1.5 times stiffer than normal tissues [27]. Stiffness promotes the assembly of actin-rich structures called invadosomes that are composed of invadopodia and podosomes, which are important for the migration of cells [28]. Maybe counterintuitively, multiple studies suggest that tumor stiffness is positively correlated with cancer invasion and metastasis (Figure 1) [26,28-31]. A study conducted on 337 breast cancer patients showed that higher matrix stiffness is associated with more aggressive cancer subtypes [32]. Enzymes produced by CAFs contribute to increased stiffness of tumor tissue and cause a higher synthesis of ECM as opposed to its degradation [5,33]. CAFs have the ability to digest the ECM in order to create tracks, as mentioned before, but they also increase its stiffness. These two apparently opposed processes give the idea of the complexity of these cells. Activated stromal cells produce LOXs, which are the primary driver of collagen cross-link formation [5,34,35]. Collagen cross-linking is able to promote matrix stiffness and cancer cell invasion [36]. When the YAP pathway is activated in CAFs, it promotes matrix stiffness, which, in turn, induces the activation of YAP in CAFs, enhancing a feedforward loop [37]. Torres et al. found lysyl oxidase like 2 (LOXL2) to be overexpressed in CAFs of CRC samples, proposing it as a predictive prognostic factor in colon cancer patients [38]. Therefore, targeting CAF-derived LOX oxidases has been suggested as a potential target against cancer migration and invasion [34].

\section{The Role of Fibroblasts in EMT and Migration}

Mesenchyme comes from a combination of the Greek words "mésos", which means middle, and "enchyme", which means cellular tissue. It refers to cells that develop into connective tissue, blood vessels, and lymphatic tissue. For the development of cancer cell metastasis, it is believed that cells need to undergo an additional step when the ECM is degraded: the acquisition of mesenchymal features. During tumor progression, the biological process of EMT occurs when epithelial cells acquire mesenchymal features (Figure 1).

EMT transcription factors (EMT-TF) are activated early in EMT and include TWIST, ZEB, and SNAIL/SLUG families. These markers can, in turn, upregulate a plethora of mesenchymal marker genes and repress those associated with an epithelial phenotype, such as genes involved in cell-cell adhesion and cell polarity [39]. It has been reported that SNAIL and ZEB play critical roles in EMT in CRC. SNAIL not only induces EMT, but also exerts cancer stem cell activities by activating interleukin-8 (IL-8) expression [40]. ZEB1 and ZEB2 are linked in a feedback loop with mir-200 and induce EMT and cancer progression [41]. STAT3 can bind directly to the ZEB1 promoter and induce its expression in CRC. In turn, ZEB1 downregulates E-cadherin, promoting EMT and invasion [42]. In CRC patients, increased ZEB2 levels strongly correlate with worse relapse-free survival 
and dismal prognosis $[43,44]$. Furthermore, Francescangeli et al. found that a population of quiescent/slow cycling cells are defined by ZEB2 expression and resist chemotherapy [43]. Two additional EMT transcription factors (TFs) appear to be implicated in CRC, i.e., forkhead box (FOX) family of TFs and the Prospero homeobox 1 (PROX1) transcription factor [45].

One of the key CAF-released inducers of the EMT-TFs, and most studied one, is transforming growth factor beta (TGF- $\beta$ ), which can modulate EMT via the TGF- $\beta$ R/SMAD pathway $[46,47]$. TGF- $\beta$ plays a dual role in cancers, as it can act in a tumor-suppressive manner in the early stages of tumor development, but can enhance tumor progression in later stages by promoting EMT and cell proliferation. In CRC, loss of SMAD4 has been shown to increase levels of TGF- $\beta$ signaling and induce EMT [48]. Lamouille et al. demonstrated that TGF- $\beta$ can activate mTORC2, an actor of the PI3K/AKT pathway, which can modulate the expression levels of genes relevant for the EMT process [49]. SMAD4 is also a negative regulator of STAT3 signaling. Knockdown of SMAD4 can, therefore, lead to aberrant STAT3 activation, which, in turn, can lead to EMT and expression of ZEB1 in CRC [45]. Overexpression of the WNT/ $\beta$-catenin pathway is another EMT promoter in CRC invasion, in which both the canonical and noncanonical pathways are involved. IWR-1, a compound that stabilizes the $\beta$-catenin destruction complex, and thereby inhibits Wnt pathway activity, can inhibit EMT progression by suppressing survivin, a downstream WNT target gene [50]. An example of a receptor of the noncanonical WNT pathway involved in EMT is frizzled 2 (Fzd2). There is a high correlation between Fzd2, its ligands WNT5a/b, and EMT markers [51]. It has been shown that Fzd2 expression enhances EMT and cell migration via interaction with STAT3. Fzd2 has, therefore, been studied as a therapeutic target reducing metastases in xenograft mouse models of CRC [45]; however, further research is required to understand the role of Fzd2 and to develop it as a therapeutic target.

\subsection{CAF-Secreted Factors}

Communication of tumor cells and fibroblasts via proinflammatory cytokines plays a crucial role in EMT. Some of these potentially metastatic CAF-secreted factors involved in EMT have been studied extensively in the past years in multiple cancer types, such as interleukin-6 (IL-6), osteopontin (OPN), hepatocyte growth factor (HGF), and CXCL12 [52-54]. CAF-derived IL-6 can induce EMT in multiple cancers, which is usually accompanied with an enhanced migratory capacity of cancer cells and consequential invasion [55-57]. We will discuss CAF-secreted IL-6 more in depth later on in this review. In cells undergoing EMT, there is usually an upregulation of several mesenchymal markers, such as vimentin, fibronectin, and N-cadherin, and a simultaneous downregulation of epithelial junction proteins, such as E-cadherin, occludins, and claudins. These regulations can cause destabilization of adherens junctions and, as a consequence, can facilitate migration and invasion.

In colorectal cancer, the cytokines HGF and OPN have been reported to be released by CAFs, causing EMT [46]. OPN is a key regulator of EMT through the TWIST pathway [58]. In addition, CXCL12 is reported to be a strong activator of EMT. It is suggested to activate the Wnt/ $\beta$-catenin pathway via a CXCR4/CXCL12 axis, which leads to EMT and to therapy resistance. Normally, this interaction of CXCR4 with CXCL12 regulates stem cell trafficking [59,60], but hyperactivation of this axis commonly induces EMT in cancers [61]. CAFs are the biggest source of CXCL12 release in the tumor microenvironment (TME), which is further stimulated by TGF- $\beta 1[61,62]$. This CXCR4/CXCL12 axis has been reported to play an important role in CRC invasion and metastasis, and is being assessed as a therapeutic CRC target [63].

CAFs can also undergo lipidomic reprograming and secrete lipid metabolites that can be taken up by CRC cells and promote migration. This occurs partly through the overexpression of vimentin and the downregulation of E-cadherin [64]. This is a relatively new insight into the CRC invasion process and further research could provide a better understanding of CRC metastasis. 


\subsection{Stiffness in EMT}

As mentioned before, ECM remodeling can result in a stiffer matrix, which can lead to tumor growth and metastasis. CAFs are key contributors to this ECM stiffness by tumor-CAF crosstalk or by inducing hypoxia within the tumor microenvironment [65]. Increased matrix rigidity has been shown to enhance the nuclear localization of transcription factor TWIST1 and its release from the cytoplasmic anchor G3BP2, promoting EMT [66]. Other well-known actors involved in EMT caused by stiffness are S100A11 membrane translocation, phosphorylation of elF4E, and autocrine TGF- $\beta 1$. These converge on SNAIL expression, a well-known actor of EMT [67]. In accordance with this, an increased matrix rigidity induces EMT in pancreatic cancer [68]. In CRC, a stiffer matrix can increase the secretion of activin A from stromal cells, which, in turn, can induce invasion through the EMT-associated protein SNAIL. Inhibition of activin A may, therefore, represent an interesting approach to target the induction of EMT [30].

\section{CAF-Tumor Communication}

In ancient Greek mythology, Hermes was an Olympian deity and functioned as the messenger of gods. This ancient mythology can be applied to modern biomedical research: communication through messengers that can make the difference between ontogenesis and oncogenesis. One example is the multifunctional cytokine TGF- $\beta$ that, in physiological conditions, regulates different mechanisms, such as morphogenesis, development, wound healing, and others, while, if deregulated, can promote aggressive phenotypes in cancers. Once activated, CAFs can secrete various messengers that can promote invasion and metastasis [69]. Some of these factors enhance EMT or ECM remodeling, as discussed in previous paragraphs. Here, we will focus on other mechanisms promoted by CAF-secreted factors.

\subsection{Communication through Exosomes}

Increasing evidence shows that exosomes are crucial in intercellular communication in cancer [70]. Exosomes are extracellular vesicles that are formed by invagination of the endosomal membrane, budding into multivesicular bodies (MVBs), and the subsequential release through fusion with the plasma membrane. Exosomes can be heterogeneous in size and contain a variety of substances, including microRNA (miRNA), messenger RNA (mRNA), DNA, proteins, and lipids. These exosome contents can act as paracrine and/or autocrine factors and can be both inside the exosomes, as well as exposed on the surface (such as TGF- $\beta$ ) [71]. Exosomes can be released by CAFs and internalized by cancer cells or the other way around, as cancer cells can release exosomes to change normal fibroblasts (NFs) into CAFs. Cancer-derived exosomes can induce differentiation of endothelial cells to CAFs, of which the exosomes, in turn, can aid in cancer cell invasion [72,73]. Recent research identified CAF-secreted exosomes as playing a critical role in tumor-CAF crosstalk and in cancer cell invasion [70]. CAF exosomes are enriched with TGF- $\beta 1$, which induces the phosphorylation of SMAD2/3 in ovarian cancer cells, promoting EMT and invasion $[70,74]$. CAFs also secrete Wnt10b in exosomes, activating the Wnt/ $\beta$-catenin pathway, EMT, and promoting breast cancer cell metastasis. In particular, fibroblasts that have low expression of $\mathrm{p} 85 \alpha$ secrete more $\mathrm{Wnt} 10 \mathrm{~b}$ in exosomes, promoting, among others, migration and invasion of cancer cells [75].

Exosomes can also contain microRNAs (miRNAs), which are involved in the regulation of cancer. Among these miRNAs, miR-21 delivered by CAFs to CRC cells through exosomes has been shown to promote metastasis [76]. In breast cancer, the expression of CAF exosomal miR-21, miR-378e, and miR-143 promotes stemness and EMT [73]. In CRC, CAF-derived exosomes can contain miR-92a-3p, which promotes stemness, invasion, metastasis, chemotherapy resistance, and EMT. This miRNA targets FBXW7 and MOAP1, whose overexpression enhances mitochondrial apoptosis and inhibition of stemness, reverting migration, invasion, and therapeutic resistance [77]. Exosomal miR-17-5p secreted by CAFs targets RUNX3 in cancer cells, which enables MYC to activate the transcription of TGF- $\beta 1$ to promote metastasis and, in turn, activate fibroblasts, forming a cancer pos- 
itive feedback loop [78]. Recently, exosomes have been receiving increased attention as potential therapeutic targets in cancer research; however, for secretory pathways to be therapeutic targets, much more insight is needed to better understand the role of exosomes in tumor-CAF crosstalk.

\subsection{Communication through TGF- $\beta / H G F$}

As mentioned before, TGF- $\beta$ and HGF play key roles in several processes of cancer development. TGF- $\beta$ was initially discovered as a growth stimulant for rat fibroblasts, but was soon found to play a major role in tumor-CAF crosstalk. TGF- $\beta$ s are cytokines that belong to the transforming growth factor superfamily. In cancer progression, it seems to play a dual role: initially, it is a suppressor of tumor progression, but then can turn into a promoter regulating fibroblast recruitment and activation [79]. It is widely accepted that TGF- $\beta$ promotes the differentiation of fibroblasts into CAFs, which, in turn, secrete TGF- $\beta$, enhancing an autocrine signaling loop that maintains the activated status of fibroblasts $[80,81]$. Once activated, CAFs secrete high levels of TGF- $\beta 1$ that can upregulate several EMT markers, such as vimentin, SNAIL, ZEB2, or long noncoding RNAs (lncRNAs) and downregulate E-cadherin [82-84]. CRC cells express TGF- $\beta$ at an early phase and hyperactivate CAFs to express this cytokine. After mutational inactivation of TGF- $\beta$ in CRC, CAFs become the new factories of TGF- $\beta$ production [81].

The proposed role of TGF- $\beta$ in CAF formation and induction of EMT suggests that targeting TGF- $\beta$ could be an interesting approach against cancer invasion and metastasis [22]. In contrast, inhibition of TGF- $\beta$ enhances expression of the pro-invasion factor HGF in CAFs, which suggests a negative regulation of TGF- $\beta$ on HGF in fibroblasts [85]. According to this, TGF- $\beta$ deficient fibroblasts increase the level of HGF, promoting invasion of mammary carcinoma cells, through MET tyrosine receptors [86].

HGF is mainly secreted by fibroblasts and is a growth factor that acts on epithelial cells. It interacts with MET to activate a signaling pathway that promotes cancer growth, survival, and invasion $[87,88]$. The constitutive activation of this pathway can occur through amplification or mutation in the MET gene in several tumors to evade regulatory mechanisms of cancer formation [89,90]. HGF can promote the transition from a preinvasive to an invasive phenotype of ductal carcinoma in situ (DCIS) cells. The activation of HGF/cMET induces the degradation of collagen IV through the expression and secretion of the protease UPA and its receptor UPAR, which facilitates migration and invasion [91]. HGF secreted by CAFs can also upregulate the IL-6 receptor in gastric cancer cells. In turn, CAF-secreted IL-6 upregulates c-MET on the same cells. These two factors both collaborate to promote the activation of STAT3 and, consequently, of TWIST1, enhancing EMT and metastasis [92]. In the colon, HGF is secreted by smooth muscle cells lining the intestine, but appears preferentially active in the crypt base [93]. In CRC, as in many other cancers, overexpression of c-MET is correlated with poor prognosis and metastasis [93]. Stromalsecreted HGF has been shown to modulate WNT signaling and diminish GSK3 activity, which, in turn, stabilizes $\beta$-catenin. This induces cancer stem cell (CSC) features in tumor cells and enhances WNT signaling in tumor cells that reside close to CAFs [94]. Overall, TGF- $\beta$ and HGF are two well-studied factors in CAF-tumor crosstalk and we will discuss the therapeutic implications further on in this review.

\subsection{Communication through IL-6/IL-8}

One of the most studied cytokines in cancer research is IL-6. It can be produced by many cells and it can promote tumor progression and therapeutic resistance [95]. IL-6 is involved in tumor-CAFs crosstalk, it can modulate the activation of fibroblasts, and, at the same time, support cancer cell growth. In particular, in esophageal carcinoma, binding its receptor (IL-6R $\alpha$ ), IL-6 can induce STAT3 and MEK/ERK signaling pathways, promoting proliferation and invasion of tumor cells [96]. As mentioned in the previous section, IL-6 has been associated with EMT and metastasis in different cancers. CAF-secreted IL-6 enhances migration and invasion of cancer cells, inducing the expression of EMT and 
metastatic-related genes. This process occurs through the activation of the JAK2/STAT3 pathway, both in lung cancer and gastric cancer [54,97]. In accordance with this, stromal IL-6 promotes EMT and, consequently, migration and therapeutic resistance in esophageal carcinoma [55]. It has been shown that CAF-derived IL-6 can also regulate the expression of osteopontin (OPN) in tumor cells, as OPN promotes invasion of head and neck cancer cells [98].

IL-8 is another molecule that plays a critical role in tumor progression and metastasis in different cancers. In ovarian cancers, CAF-derived IL-8 promotes normal fibroblast proliferation and stemness of tumor cells, activating the Notch-3 signaling pathway [99]. In addition, in pancreatic cancer, a subtype of CAFs with senescent features secretes more IL-8 than non-senescent CAFs. This senescent subset promotes pancreatic cancer cell invasion and metastasis [100]. Furthermore, melanoma cells cocultured with CAFs or treated with conditioned medium derived from CAFs display increased invasive potential. This can be reversed using IL-6 and IL-8 neutralizing antibodies, suggesting that the simultaneous inhibition of both cytokines is a promising approach in melanoma [101]. In CRC, IL-6 plays a significant clinical pathological role, as IL-6 is positively correlated with tumor TNM stage and associated with invasion depth and lymph node metastasis [102]. Furthermore, the expression of IL- 6 and integrin $\beta 6$ in CRC samples correlate with each other. IL-6 expression induces CRC invasion via the upregulation of integrin $\beta 6$ through the IL- 6 receptor/STAT-3 signaling [103]. Several clinical studies have been conducted targeting the IL-6 pathway in CRC; however, no significant anticancer effects have been observed yet with IL-6 monoclonal antibodies alone [104-107].

IL-8 is another potential therapeutic target, as the expression of IL- 8 in the tumor microenvironment induces colon cancer growth and metastasis [108]. However, to date, the IL-8 inhibitors have also not yet been proven effective enough on their own [109-111].

\subsection{Communication through Other Factors}

Beside these major elements, there are many other factors that play a role in the induction of migration and invasion by CAFs. For example, interleukin-32 (IL-32) interacts with integrin- $\beta 3$ on cancer cells and activates p38 MAPK pathway, which promotes EMT and invasion in breast cancer [112]. VCAM-1 is another highly secreted factor in CAF-conditioned medium as compared to conditioned medium of normal fibroblasts. This promotes growth and invasion of lung cancer cells through interaction with VLA-4 and the subsequent activation of the AKT and MAPK signaling pathway [113]. In CRC, CAFs secrete WNT2 in order to promote migration and invasion of cancer cells [114]. Furthermore, WNT2 acts in an autocrine manner in CRC by activating the canonical WNT signaling pathway in fibroblasts, and enhancing migration and invasion of both CAFs and CRC cells [115]. Moreover, CAFs stimulated with TGF- $\beta$ secrete interleukin-11 (IL-11), which can promote metastasis in CRC through the GP130/STAT3 pathway [116].

\section{CAF-Targeted Therapies}

Therapy is derived quite literally from the Greek word "therapeia", which means curing and healing. Differentially expressed CAF genes are potential targets for CAFdirected therapies. These genes are usually involved in carcinogenesis, angiogenesis, invasion, and metastasis. Targeting these genes and pathways opens possibilities to sensitize patients to therapies to reverse drug resistance or inhibit tumor progression. CAF targets are determined on genomic, transcriptional, and proteomic levels in CRC patients and cell lines. Many pathways are stimulated by CAFs, which offer a variety of available targets [5].

CAFs also have the ability to create an immunosuppressive TME, which inhibits both the innate and adaptive immune responses. CAFs can induce $\mathrm{T}$ cell anergy, inhibit $\mathrm{T}$ cell proliferation, recruit and activate T regulatory cells (Tregs), and prevent the access of immune cells to cancer cells through ECM remodeling [117]. In CRC, CAFs are able to recruit monocytes and facilitate their adhesion on tumor cells. Together with them, CAFs 
suppress the functions of natural killer cells (NK cells), which contribute to creating an immune-suppressive environment [118]. The ability of CAFs to promote the polarization of macrophages toward an immuno-suppressive and tumor-promoting phenotype has been described in different tumors $[119,120]$. CAFs can promote dysfunction and impair the cytotoxic function of NK cells. Similarly, in melanoma CAFs, secreting high levels of active MMPs decrease the lysing capacity of NK cells [121]. CAFs play a key role in cancer-related immune regulation and this topic deserves a more extensive review, for which we gladly refer to the overview by Ziani et al. [122].

As we will focus on signals that regulate EMT, migration, and invasion, we will not elucidate on immunotherapy. The therapies in the section are summarized in Table 1.

Table 1. Summary of CAF-targeted therapies.

\begin{tabular}{|c|c|c|c|c|c|}
\hline Pathway & Compound & Targets & Cancer & Mechanism & Ref. \\
\hline MMP9 & GS-5745 & MMP9 & Colorectal & $\begin{array}{l}\text { Inhibition of tumor growth } \\
\text { and metastasis }\end{array}$ & [123] \\
\hline \multirow[t]{2}{*}{ Hedgehog } & & Smo & Pancreatic & $\begin{array}{c}\text { Decrease in fibroblast } \\
\text { accumulation and easier } \\
\text { drug delivery }\end{array}$ & [124] \\
\hline & & Shh/Gli pathway & Breast & $\begin{array}{l}\text { Reduction in cell migration } \\
\text { and invasion }\end{array}$ & [125] \\
\hline \multirow{4}{*}{ TGF- $\beta$} & LY2109761 & TGF- $\beta$ receptor 1 & Hepatic & $\begin{array}{l}\text { Reduction in the stromal } \\
\text { compartment }\end{array}$ & [126] \\
\hline & Galunisertib & & Ovarian & $\begin{array}{l}\text { Prevention of CAF } \\
\text { activation and reduction in } \\
\text { proliferation and invasion }\end{array}$ & [127] \\
\hline & Realaxin-2 & Smad2 pathway & Pancreatic & $\begin{array}{l}\text { Decrease in tumor growth } \\
\text { and increase in sensitivity of } \\
\text { gemcitabine }\end{array}$ & [128] \\
\hline & Artesiminin & TGF- $\beta$ & Breast & $\begin{array}{l}\text { Inactivation of CAFs and } \\
\text { inhibition of cancer growth } \\
\text { and metastasis }\end{array}$ & [129] \\
\hline \multirow{3}{*}{ Reprograming } & ATRA & \multirow[t]{3}{*}{ HSP47 } & \multirow[t]{3}{*}{ Pancreatic } & $\begin{array}{l}\text { Reprograming of PSCs, } \\
\text { reduction in Wnt signaling, } \\
\text { and modulation of } \\
\text { proliferation, apoptosis, and } \\
\text { invasion }\end{array}$ & [130] \\
\hline & $\begin{array}{c}\text { Nano-system } \\
\text { (ATRA + anti } \\
\text { HSP47) }\end{array}$ & & & $\begin{array}{l}\text { Reprograming of PSCs, } \\
\text { reduction in ECM } \\
\text { production, and increase in } \\
\text { chemotherapeutic effects }\end{array}$ & [131] \\
\hline & VDR ligand & & & $\begin{array}{l}\text { Induction of quiescent PSCs } \\
\text { from activated PSCs }\end{array}$ & [132] \\
\hline
\end{tabular}

\subsection{CAF Targeting via MMP9}

MMPs are highly expressed in a wide range of tumor types and have been strongly implicated to play a key role in tumor invasion and metastasis [133]. An anti-MMP9 monoclonal antibody GS-5745 was shown to successfully inhibit tumor growth and metastasis in a colorectal cancer preclinical study in mice. However, in clinical trials, these MMP inhibitors did not show an antitumor effect [34,123]. Many clinical trials with MMP9 inhibitors have failed due to toxicity or insufficient clinical benefit. Toxicity was shown to be the consequence of MMP inhibitors circulating systemically; therefore, it would be interesting to focus on local application, such as targeted delivery or topical administration [134]. On top of that, failures were attributed to bad clinical design and non-specificity of MMP9 inhibitors [34]. As members of the MMP family are essential for the homeostasis maintenance, inflammatory responses, angiogenesis, and wound healing, it is of impor- 
tance to focus on selectivity, as a broad range of MMP inhibitors can have detrimental consequences [135-137]. Furthermore, the specificity of these inhibitors is often low with off-target effects. However, a key reason for these failures might also be the lack of knowledge on MMP roles and functions in the ECM microenvironment. Therefore, MMP9 still remains a potential target that requires further research and optimization of specificity.

\subsection{CAF Targeting via Hedgehog Signaling}

Hedgehog $(\mathrm{Hh})$ signaling is, in several cancers, a crucial modifier of CAFs and CAFinduced cancer growth, invasion, and metastasis [125,138-140]. Hedgehog signaling includes Sonic hedgehog (Shh), Desert hedgehog (Dhh), and Indian hedgehog (Ihh), all ligands that can bind to the transmembrane protein Patched [141]. In the absence of Hh, its ligand Patched represses the transmembrane receptor smoothened (SMO), leading to the proteolytic cleavage of full-length glioma-associated oncogene (Gli) to Gli repressor (GliR). Both Gli and GliR bind specific promoter regions and can, respectively, enhance or repress transcription of Hh target genes [141]. When bound by ligand, Patched no longer represses SMO and the Hh signaling pathway is activated, which has been shown to increase cell migration and invasion in pancreatic cancer and human gliomas by upregulating MMP9 expression [138]. As mutations in Patched1 or SMO can result in aberrant Hh pathway activation, $\mathrm{SMO}$ is often a target of the Hh pathway inhibitors in cancer therapeutics [142]. Inhibition of the Hh pathway or Shh ligands reportedly reduces tumor growth and distant metastases of PDAC [143]. Interestingly, inactivation of the Shh/Gli1 axis significantly reduces cell migration and invasiveness in breast cancer cells [125]. Desmoplasia in pancreatic cancer not only facilitates tumor growth, but is also suggested to protect tumor cells against chemotherapy due to elevated interstitial pressure, which prevents the chemotherapy from reaching the cancer cells. Here, the treatment with an SMO inhibitor decreased fibroblast numbers and increased vasculature density, leading to more effective chemotherapy delivery [124,143]. Unfortunately, clinical trials with PDAC patients using these SMO inhibitors in combination with gemcitabine have shown little to no efficacy [144]. Another phase II clinical trial of an SMO inhibitor and gemcitabine combination therapy was suspended when patients receiving this treatment had a worse clinical outcome than the group that received a placebo [143]. A proposed reason for these failures is that the desmoplastic reaction induced by Hh signaling also restrains pancreatic cancer cells from spreading to metastatic sites, which is abolished by the treatment. Balancing these effects of the stromal compartment may be crucial in the development of effective therapies.

\subsection{CAF Targeting via TGF- $\beta$}

TGF- $\beta$ is a potential CAF-derived target that can potentially prevent metastasis by treating patients at an early stage. Different studies demonstrate that targeting this factor is a promising approach against CAF-mediated cancer progression [126-129,145].

The TGF- $\beta$ receptor 1 inhibitor LY2109761 can affect tumor progression, targeting the crosstalk between stromal cells and cancer cells. In particular, this molecule can reduce the stromal component of hepatocellular carcinoma (HCC) and the production of connective tissue growth factor, which is highly produced by invasive HCC cells [126]. Galunisertib, another TGF- $\beta$ receptor 1 inhibitor, prevents the TGF- $\beta$-induced fibroblast activation in ovarian cancer and, as a consequence, reduces migration and invasion of the cancer cells [127]. Similarly, in pancreatic cancer, inhibition of TGF- $\beta$ activation of pancreatic stellate cells by the peptide hormone relaxin-2 can decrease tumor growth and potentiate the effect of the chemotherapeutic drug gemcitabine [128].

Artemisinin derivatives have also been shown to suppress TGF- $\beta$ signaling in CAFs. This leads to the inactivation of CAFs and inhibition of cancer growth and metastasis. These results make artemisinin derivatives new potential therapeutic agents in breast cancer [129]. 


\subsection{CAF Reprograming}

The role of CAFs in promoting tumor progression prompted researchers to think that depletion of these activated stromal cells could be a potential therapeutic strategy. Surprisingly, the depletion of myofibroblasts in pancreatic ductal adenocarcinoma (PDAC) does not improve mice survival and leads to more aggressive, undifferentiated tumors $[146,147]$. Therefore, another approach for therapies against CAFs is the reprograming of tumor stroma. This approach consists of remodeling activated fibroblasts into quiescent fibroblasts that are normally present in homeostatic conditions. The aim of this approach is to inhibit the tumor-promoting functions of CAFs and CAF-induced therapy resistance. An example of this new strategy is in pancreatic cancer, where the hypovascularity of the stroma limits therapeutic efficacy. Based on the observation that quiescent pancreatic stellate cells (PSCs) store retinol, while the activated ones lose it, treatment of these cells with all-trans retinoic acid (ATRA) is assessed to restore physiological activity of PSCs. These reprogramed PSCs have the ability to produce secreted frizzled-related protein 4 (sFRP4), which reduces Wnt signaling in cancer cells and affects proliferation, apoptosis, and invasion of these cells [130]. A nano-system that combines ATRA and HSP47 small interfering RNA (siRNA), the latter of which is a collagen-specific chaperon crucial for the secretion of collagen protein into the ECM, was used to restore the physiological condition of PSCs. This reduces ECM production and, consequently, enhances pancreatic cancer chemotherapy [131]. In addition, vitamin D receptor (VDR) ligands promote the transition from activated to quiescent pancreatic stellate cells (PSCs), which lowers the secretion of tumor-promoting cytokines from these cells [132].

Currently, there are no main CAF-directed therapies used in CRC patients. Nevertheless, several of the inhibitory strategies described above are being tested. Applying such inhibitors, likely in combination with chemotherapy receptor-targeting therapies or radiotherapy, might improve the treatment of CRC patients and hopefully lower the incidence of metastatic spreading.

\section{Conclusions}

Cancer-related death is largely attributed to the complex metastatic process. The recognition that CAFs are central players in this process has boosted CAF research in the last decade. Understanding the underlying role CAFs play is, therefore, pivotal, as it seems that targeting CAFs may be necessary to prevent therapy resistance and metastasis. Clinical trials show promising results, but also prove that CAF-directed therapies are challenging and still have a long way to go to get from bench to bedside. Surprisingly, CAFs in CRC are still relatively understudied, despite the fact that CRC contains a subset with high levels of stromal cells [148]. The fact that this so-called CMS4 mesenchymal subtype has the worst prognosis, with an elevated metastatic capacity, makes it an interesting target for CAF-directed therapy. However, not much is known about the differences in the role of CAFs between the distinct CRC subtypes or even the specific role of CAFs in CMS4. Hence, further research is essential in this field to reduce cancer-related deaths due to metastasis. Research on this topic has shown that targeting CAFs can have opposing outcomes and sometimes result in an even more aggressive phenotype. Therefore, it is of importance to get a better understanding of different populations of fibroblasts surrounding tumors and specifically target those causing invasion and metastasis.

Author Contributions: P.J.A., C.L., M.H. and J.P.M. contributed to the writing, review and editing. All authors have read and agreed to the published version of the manuscript.

Funding: Paris J Asif: Ciro Longobardi, and Jan Paul Medema were funded by Oncode and Dutch Cancer Society grant 10150. Michael Hahne was funded by INSERM (21CM047-00), INCA (PLBIO21222), and ANR (CE14 CILCOL).

Conflicts of Interest: The authors declare no conflict of interest. 


\section{References}

1. Retsas, S. Cancer and the arts: Metastasis-as perceived through the ages. ESMO Open 2017, 2, e000226. [CrossRef] [PubMed]

2. Attieh, Y.; Clark, A.G.; Grass, C.; Richon, S.; Pocard, M.; Mariani, P.; Elkhatib, N.; Betz, T.; Gurchenkov, B.; Vignjevic, D.M. Cancer-associated fibroblasts lead tumor invasion through integrin-beta3-dependent fibronectin assembly. J. Cell Biol. 2017, 216, 3509-3520. [CrossRef] [PubMed]

3. Winkler, J.; Abisoye-Ogunniyan, A.; Metcalf, K.J.; Werb, Z. Concepts of extracellular matrix remodelling in tumour progression and metastasis. Nat. Commun. 2020, 11, 5120. [CrossRef]

4. Arina, A.; Idel, C.; Hyjek, E.M.; Alegre, M.L.; Wang, Y.; Bindokas, V.P.; Weichselbaum, R.R.; Schreiber, H. Tumor-associated fibroblasts predominantly come from local and not circulating precursors. Proc. Natl. Acad. Sci. USA 2016, 113, 7551-7556. [CrossRef] [PubMed]

5. Sahai, E.; Astsaturov, I.; Cukierman, E.; DeNardo, D.G.; Egeblad, M.; Evans, R.M.; Fearon, D.; Greten, F.R.; Hingorani, S.R.; Hunter, T.; et al. A framework for advancing our understanding of cancer-associated fibroblasts. Nat. Rev. Cancer 2020, 20, 174-186. [CrossRef]

6. Raz, Y.; Cohen, N.; Shani, O.; Bell, R.E.; Novitskiy, S.V.; Abramovitz, L.; Levy, C.; Milyavsky, M.; Leider-Trejo, L.; Moses, H.L.; et al. Bone marrow-derived fibroblasts are a functionally distinct stromal cell population in breast cancer. J. Exp. Med. 2018, 215, 3075-3093. [CrossRef]

7. Bochet, L.; Lehuede, C.; Dauvillier, S.; Wang, Y.Y.; Dirat, B.; Laurent, V.; Dray, C.; Guiet, R.; Maridonneau-Parini, I.; Le Gonidec, S.; et al. Adipocyte-derived fibroblasts promote tumor progression and contribute to the desmoplastic reaction in breast cancer. Cancer Res. 2013, 73, 5657-5668. [CrossRef]

8. Ohlund, D.; Handly-Santana, A.; Biffi, G.; Elyada, E.; Almeida, A.S.; Ponz-Sarvise, M.; Corbo, V.; Oni, T.E.; Hearn, S.A.; Lee, E.J.; et al. Distinct populations of inflammatory fibroblasts and myofibroblasts in pancreatic cancer. J. Exp. Med. 2017, 214, 579-596. [CrossRef] [PubMed]

9. Friedman, G.; Levi-Galibov, O.; David, E.; Bornstein, C.; Giladi, A.; Dadiani, M.; Mayo, A.; Halperin, C.; Pevsner-Fischer, M.; Lavon, H.; et al. Cancer-associated fibroblast compositions change with breast cancer progression linking the ratio of S100A4+ and PDPN+ CAFs to clinical outcome. Nat. Cancer 2020, 1, 692-708. [CrossRef]

10. Elwakeel, E.; Bruggemann, M.; Fink, A.F.; Schulz, M.H.; Schmid, T.; Savai, R.; Brune, B.; Zarnack, K.; Weigert, A. Phenotypic Plasticity of Fibroblasts during Mammary Carcinoma Development. Int. J. Mol. Sci. 2019, 20, 4438. [CrossRef]

11. Li, H.; Courtois, E.T.; Sengupta, D.; Tan, Y.; Chen, K.H.; Goh, J.J.L.; Kong, S.L.; Chua, C.; Hon, L.K.; Tan, W.S.; et al. Reference component analysis of single-cell transcriptomes elucidates cellular heterogeneity in human colorectal tumors. Nat. Genet. 2017, 49, 708-718. [CrossRef]

12. Kanzaki, R.; Pietras, K. Heterogeneity of cancer-associated fibroblasts: Opportunities for precision medicine. Cancer Sci. 2020, 111, 2708-2717. [CrossRef] [PubMed]

13. Mhaidly, R.; Mechta-Grigoriou, F. Fibroblast heterogeneity in tumor micro-environment: Role in immunosuppression and new therapies. Semin. Immunol 2020, 48, 101417. [CrossRef] [PubMed]

14. Nurmik, M.; Ullmann, P.; Rodriguez, F.; Haan, S.; Letellier, E. In search of definitions: Cancer-associated fibroblasts and their markers. Int. J. Cancer 2020, 146, 895-905. [CrossRef] [PubMed]

15. Naba, A.; Clauser, K.R.; Ding, H.; Whittaker, C.A.; Carr, S.A.; Hynes, R.O. The extracellular matrix: Tools and insights for the "omics" era. Matrix Biol. 2016, 49, 10-24. [CrossRef] [PubMed]

16. Eble, J.A.; Niland, S. The extracellular matrix in tumor progression and metastasis. Clin. Exp. Metastasis 2019, 36, 171-198. [CrossRef]

17. Chen, L.; Zhu, M.; Yu, S.; Hai, L.; Zhang, L.; Zhang, C.; Zhao, P.; Zhou, H.; Wang, S.; Yang, X. Arg kinase mediates CXCL12/CXCR4induced invadopodia formation and invasion of glioma cells. Exp. Cell Res. 2020, 389, 111893. [CrossRef]

18. Bonnans, C.; Chou, J.; Werb, Z. Remodelling the extracellular matrix in development and disease. Nat. Rev. Mol. Cell Biol. 2014, 15, 786-801. [CrossRef]

19. Lu, P.; Weaver, V.M.; Werb, Z. The extracellular matrix: A dynamic niche in cancer progression. J. Cell Biol. 2012, 196, 395-406. [CrossRef]

20. Santi, A.; Kugeratski, F.G.; Zanivan, S. Cancer Associated Fibroblasts: The Architects of Stroma Remodeling. Proteomics 2018, 18, e1700167. [CrossRef] [PubMed]

21. Li, Z.L.; Wang, Z.J.; Wei, G.H.; Yang, Y.; Wang, X.W. Changes in extracellular matrix in different stages of colorectal cancer and their effects on proliferation of cancer cells. World J. Gastrointest Oncol. 2020, 12, 267-275. [CrossRef]

22. Erdogan, B.; Webb, D.J. Cancer-associated fibroblasts modulate growth factor signaling and extracellular matrix remodeling to regulate tumor metastasis. Biochem. Soc. Trans. 2017, 45, 229-236. [CrossRef] [PubMed]

23. Li, J.; Jia, Z.; Kong, J.; Zhang, F.; Fang, S.; Li, X.; Li, W.; Yang, X.; Luo, Y.; Lin, B.; et al. Carcinoma-Associated Fibroblasts Lead the Invasion of Salivary Gland Adenoid Cystic Carcinoma Cells by Creating an Invasive Track. PLoS ONE 2016, 11, e0150247. [CrossRef] [PubMed]

24. Gaggioli, C.; Hooper, S.; Hidalgo-Carcedo, C.; Grosse, R.; Marshall, J.F.; Harrington, K.; Sahai, E. Fibroblast-led collective invasion of carcinoma cells with differing roles for RhoGTPases in leading and following cells. Nat. Cell Biol. 2007, 9, 1392-1400. [CrossRef]

25. Neri, S.; Ishii, G.; Hashimoto, H.; Kuwata, T.; Nagai, K.; Date, H.; Ochiai, A. Podoplanin-expressing cancer-associated fibroblasts lead and enhance the local invasion of cancer cells in lung adenocarcinoma. Int. J. Cancer 2015, 137, 784-796. [CrossRef] [PubMed] 
26. Kalli, M.; Stylianopoulos, T. Defining the Role of Solid Stress and Matrix Stiffness in Cancer Cell Proliferation and Metastasis. Front. Oncol. 2018, 8, 55. [CrossRef]

27. Voutouri, C.; Mpekris, F.; Papageorgis, P.; Odysseos, A.D.; Stylianopoulos, T. Role of constitutive behavior and tumor-host mechanical interactions in the state of stress and growth of solid tumors. PLoS ONE 2014, 9, e104717. [CrossRef] [PubMed]

28. Kai, F.; Laklai, H.; Weaver, V.M. Force Matters: Biomechanical Regulation of Cell Invasion and Migration in Disease. Trends Cell Biol. 2016, 26, 486-497. [CrossRef]

29. Acerbi, I.; Cassereau, L.; Dean, I.; Shi, Q.; Au, A.; Park, C.; Chen, Y.Y.; Liphardt, J.; Hwang, E.S.; Weaver, V.M. Human breast cancer invasion and aggression correlates with ECM stiffening and immune cell infiltration. Integr. Biol. 2015, 7, 1120-1134. [CrossRef]

30. Bauer, J.; Emon, M.A.B.; Staudacher, J.J.; Thomas, A.L.; Zessner-Spitzenberg, J.; Mancinelli, G.; Krett, N.; Saif, M.T.; Jung, B. Increased stiffness of the tumor microenvironment in colon cancer stimulates cancer associated fibroblast-mediated prometastatic activin A signaling. Sci. Rep. 2020, 10, 50. [CrossRef]

31. Gkretsi, V.; Stylianopoulos, T. Cell Adhesion and Matrix Stiffness: Coordinating Cancer Cell Invasion and Metastasis. Front. Oncol. 2018, 8, 145. [CrossRef] [PubMed]

32. Chang, J.M.; Park, I.A.; Lee, S.H.; Kim, W.H.; Bae, M.S.; Koo, H.R.; Yi, A.; Kim, S.J.; Cho, N.; Moon, W.K. Stiffness of tumours measured by shear-wave elastography correlated with subtypes of breast cancer. Eur. Radiol. 2013, 23, 2450-2458. [CrossRef] [PubMed]

33. Mohammadi, H.; Sahai, E. Mechanisms and impact of altered tumour mechanics. Nat. Cell Biol. 2018, 20, 766-774. [CrossRef]

34. Liu, T.; Zhou, L.; Li, D.; Andl, T.; Zhang, Y. Cancer-Associated Fibroblasts Build and Secure the Tumor Microenvironment. Front. Cell Dev. Biol. 2019, 7, 60. [CrossRef]

35. Pankova, D.; Chen, Y.; Terajima, M.; Schliekelman, M.J.; Baird, B.N.; Fahrenholtz, M.; Sun, L.; Gill, B.J.; Vadakkan, T.J.; Kim, M.P.; et al. Cancer-Associated Fibroblasts Induce a Collagen Cross-link Switch in Tumor Stroma. Mol. Cancer Res. 2016, 14, 287-295. [CrossRef]

36. Levental, K.R.; Yu, H.; Kass, L.; Lakins, J.N.; Egeblad, M.; Erler, J.T.; Fong, S.F.; Csiszar, K.; Giaccia, A.; Weninger, W.; et al. Matrix crosslinking forces tumor progression by enhancing integrin signaling. Cell 2009, 139, 891-906. [CrossRef] [PubMed]

37. Calvo, F.; Ege, N.; Grande-Garcia, A.; Hooper, S.; Jenkins, R.P.; Chaudhry, S.I.; Harrington, K.; Williamson, P.; Moeendarbary, E.; Charras, G.; et al. Mechanotransduction and YAP-dependent matrix remodelling is required for the generation and maintenance of cancer-associated fibroblasts. Nat. Cell Biol. 2013, 15, 637-646. [CrossRef] [PubMed]

38. Torres, S.; Garcia-Palmero, I.; Herrera, M.; Bartolome, R.A.; Pena, C.; Fernandez-Acenero, M.J.; Padilla, G.; Pelaez-Garcia, A.; Lopez-Lucendo, M.; Rodriguez-Merlo, R.; et al. LOXL2 Is Highly Expressed in Cancer-Associated Fibroblasts and Associates to Poor Colon Cancer Survival. Clin. Cancer Res. 2015, 21, 4892-4902. [CrossRef]

39. Brabletz, T.; Kalluri, R.; Nieto, M.A.; Weinberg, R.A. EMT in cancer. Nat. Rev. Cancer 2018, 18, 128-134. [CrossRef] [PubMed]

40. Hwang, W.L.; Yang, M.H.; Tsai, M.L.; Lan, H.Y.; Su, S.H.; Chang, S.C.; Teng, H.W.; Yang, S.H.; Lan, Y.T.; Chiou, S.H.; et al. SNAIL regulates interleukin-8 expression, stem cell-like activity, and tumorigenicity of human colorectal carcinoma cells. Gastroenterology 2011, 141, 279-291. [CrossRef]

41. Brabletz, S.; Brabletz, T. The ZEB/miR-200 feedback loop-a motor of cellular plasticity in development and cancer? EMBO Rep. 2010, 11, 670-677. [CrossRef]

42. Xiong, H.; Hong, J.; Du, W.; Lin, Y.W.; Ren, L.L.; Wang, Y.C.; Su, W.Y.; Wang, J.L.; Cui, Y.; Wang, Z.H.; et al. Roles of STAT3 and ZEB1 proteins in E-cadherin down-regulation and human colorectal cancer epithelial-mesenchymal transition. J. Biol. Chem. 2012, 287, 5819-5832. [CrossRef]

43. Francescangeli, F.; Contavalli, P.; De Angelis, M.L.; Careccia, S.; Signore, M.; Haas, T.L.; Salaris, F.; Baiocchi, M.; Boe, A.; Giuliani, A.; et al. A pre-existing population of ZEB2(+) quiescent cells with stemness and mesenchymal features dictate chemoresistance in colorectal cancer. J. Exp. Clin. Cancer Res. 2020, 39, 2. [CrossRef]

44. Sreekumar, R.; Harris, S.; Moutasim, K.; DeMateos, R.; Patel, A.; Emo, K.; White, S.; Yagci, T.; Tulchinsky, E.; Thomas, G.; et al. Assessment of Nuclear ZEB2 as a Biomarker for Colorectal Cancer Outcome and TNM Risk Stratification. JAMA Netw. Open 2018, 1, e183115. [CrossRef]

45. Vu, T.; Datta, P.K. Regulation of EMT in Colorectal Cancer: A Culprit in Metastasis. Cancers 2017, 9, 171. [CrossRef] [PubMed]

46. Fiori, M.E.; Di Franco, S.; Villanova, L.; Bianca, P.; Stassi, G.; De Maria, R. Cancer-associated fibroblasts as abettors of tumor progression at the crossroads of EMT and therapy resistance. Mol. Cancer 2019, 18, 70. [CrossRef] [PubMed]

47. Xu, J.; Lamouille, S.; Derynck, R. TGF-beta-induced epithelial to mesenchymal transition. Cell Res. 2009, 19, 156-172. [CrossRef] [PubMed]

48. Pohl, M.; Radacz, Y.; Pawlik, N.; Schoeneck, A.; Baldus, S.E.; Munding, J.; Schmiegel, W.; Schwarte-Waldhoff, I.; Reinacher-Schick, A. SMAD4 mediates mesenchymal-epithelial reversion in SW480 colon carcinoma cells. Anticancer Res. 2010, 30, $2603-2613$. [PubMed]

49. Lamouille, S.; Connolly, E.; Smyth, J.W.; Akhurst, R.J.; Derynck, R. TGF-beta-induced activation of mTOR complex 2 drives epithelial-mesenchymal transition and cell invasion. J. Cell Sci. 2012, 125, 1259-1273. [CrossRef] [PubMed]

50. Lee, S.C.; Kim, O.H.; Lee, S.K.; Kim, S.J. IWR-1 inhibits epithelial-mesenchymal transition of colorectal cancer cells through suppressing Wnt/beta-catenin signaling as well as survivin expression. Oncotarget 2015, 6, 27146-27159. [CrossRef] 
51. Gujral, T.S.; Chan, M.; Peshkin, L.; Sorger, P.K.; Kirschner, M.W.; MacBeath, G. A noncanonical Frizzled2 pathway regulates epithelial-mesenchymal transition and metastasis. Cell 2014, 159, 844-856. [CrossRef] [PubMed]

52. Lenos, K.J.; Miedema, D.M.; Lodestijn, S.C.; Nijman, L.E.; van den Bosch, T.; Romero Ros, X.; Lourenco, F.C.; Lecca, M.C.; van der Heijden, M.; van Neerven, S.M.; et al. Stem cell functionality is microenvironmentally defined during tumour expansion and therapy response in colon cancer. Nat. Cell Biol. 2018, 20, 1193-1202. [CrossRef] [PubMed]

53. Orimo, A.; Gupta, P.B.; Sgroi, D.C.; Arenzana-Seisdedos, F.; Delaunay, T.; Naeem, R.; Carey, V.J.; Richardson, A.L.; Weinberg, R.A. Stromal fibroblasts present in invasive human breast carcinomas promote tumor growth and angiogenesis through elevated SDF-1/CXCL12 secretion. Cell 2005, 121, 335-348. [CrossRef]

54. Wu, X.; Tao, P.; Zhou, Q.; Li, J.; Yu, Z.; Wang, X.; Li, J.; Li, C.; Yan, M.; Zhu, Z.; et al. IL-6 secreted by cancer-associated fibroblasts promotes epithelial-mesenchymal transition and metastasis of gastric cancer via JAK2/STAT3 signaling pathway. Oncotarget 2017, 8, 20741-20750. [CrossRef] [PubMed]

55. Ebbing, E.A.; van der Zalm, A.P.; Steins, A.; Creemers, A.; Hermsen, S.; Rentenaar, R.; Klein, M.; Waasdorp, C.; Hooijer, G.K.J.; Meijer, S.L.; et al. Stromal-derived interleukin 6 drives epithelial-to-mesenchymal transition and therapy resistance in esophageal adenocarcinoma. Proc. Natl. Acad. Sci. USA 2019, 116, 2237-2242. [CrossRef]

56. Goulet, C.R.; Champagne, A.; Bernard, G.; Vandal, D.; Chabaud, S.; Pouliot, F.; Bolduc, S. Cancer-associated fibroblasts induce epithelial-mesenchymal transition of bladder cancer cells through paracrine IL-6 signalling. BMC Cancer 2019, 19, 137. [CrossRef]

57. Zhou, J.; Zhang, C.; Pan, J.; Chen, L.; Qi, S.T. Interleukin6 induces an epithelialmesenchymal transition phenotype in human adamantinomatous craniopharyngioma cells and promotes tumor cell migration. Mol. Med. Rep. 2017, 15, 4123-4131. [CrossRef] [PubMed]

58. Kothari, A.N.; Arffa, M.L.; Chang, V.; Blackwell, R.H.; Syn, W.K.; Zhang, J.; Mi, Z.; Kuo, P.C. Osteopontin-A Master Regulator of Epithelial-Mesenchymal Transition. J. Clin. Med. 2016, 5, 39. [CrossRef] [PubMed]

59. Hu, T.H.; Yao, Y.; Yu, S.; Han, L.L.; Wang, W.J.; Guo, H.; Tian, T.; Ruan, Z.P.; Kang, X.M.; Wang, J.; et al. SDF-1/CXCR4 promotes epithelial-mesenchymal transition and progression of colorectal cancer by activation of the Wnt/beta-catenin signaling pathway. Cancer Lett. 2014, 354, 417-426. [CrossRef]

60. Ping, Y.F.; Yao, X.H.; Jiang, J.Y.; Zhao, L.T.; Yu, S.C.; Jiang, T.; Lin, M.C.; Chen, J.H.; Wang, B.; Zhang, R.; et al. The chemokine CXCL12 and its receptor CXCR4 promote glioma stem cell-mediated VEGF production and tumour angiogenesis via PI3K/AKT signalling. J. Pathol. 2011, 224, 344-354. [CrossRef]

61. Zhou, W.; Guo, S.; Liu, M.; Burow, M.E.; Wang, G. Targeting CXCL12/CXCR4 Axis in Tumor Immunotherapy. Curr. Med. Chem. 2019, 26, 3026-3041. [CrossRef]

62. Tang, X.; Tu, G.; Yang, G.; Wang, X.; Kang, L.; Yang, L.; Zeng, H.; Wan, X.; Qiao, Y.; Cui, X.; et al. Autocrine TGF-beta1/miR200s / miR-221/DNMT3B regulatory loop maintains CAF status to fuel breast cancer cell proliferation. Cancer Lett. 2019, 452, 79-89. [CrossRef]

63. Khare, T.; Bissonnette, M.; Khare, S. CXCL12-CXCR4/CXCR7 Axis in Colorectal Cancer: Therapeutic Target in Preclinical and Clinical Studies. Int. J. Mol. Sci. 2021, 22, 7371. [CrossRef]

64. Gong, J.; Lin, Y.; Zhang, H.; Liu, C.; Cheng, Z.; Yang, X.; Zhang, J.; Xiao, Y.; Sang, N.; Qian, X.; et al. Reprogramming of lipid metabolism in cancer-associated fibroblasts potentiates migration of colorectal cancer cells. Cell Death Dis. 2020, 11, 267. [CrossRef] [PubMed]

65. Najafi, M.; Farhood, B.; Mortezaee, K. Extracellular matrix (ECM) stiffness and degradation as cancer drivers. J. Cell Biochem. 2019, 120, 2782-2790. [CrossRef]

66. Wei, S.C.; Fattet, L.; Tsai, J.H.; Guo, Y.; Pai, V.H.; Majeski, H.E.; Chen, A.C.; Sah, R.L.; Taylor, S.S.; Engler, A.J.; et al. Matrix stiffness drives epithelial-mesenchymal transition and tumour metastasis through a TWIST1-G3BP2 mechanotransduction pathway. Nat. Cell Biol. 2015, 17, 678-688. [CrossRef] [PubMed]

67. Dong, Y.; Zheng, Q.; Wang, Z.; Lin, X.; You, Y.; Wu, S.; Wang, Y.; Hu, C.; Xie, X.; Chen, J.; et al. Higher matrix stiffness as an independent initiator triggers epithelial-mesenchymal transition and facilitates HCC metastasis. J. Hematol. Oncol. $2019,12,112$. [CrossRef] [PubMed]

68. Rice, A.J.; Cortes, E.; Lachowski, D.; Cheung, B.C.H.; Karim, S.A.; Morton, J.P.; Del Rio Hernandez, A. Matrix stiffness induces epithelial-mesenchymal transition and promotes chemoresistance in pancreatic cancer cells. Oncogenesis 2017, 6, e352. [CrossRef]

69. Linares, J.; Marin-Jimenez, J.A.; Badia-Ramentol, J.; Calon, A. Determinants and Functions of CAFs Secretome During Cancer Progression and Therapy. Front. Cell Dev. Biol. 2020, 8, 621070. [CrossRef] [PubMed]

70. Dai, J.; Su, Y.; Zhong, S.; Cong, L.; Liu, B.; Yang, J.; Tao, Y.; He, Z.; Chen, C.; Jiang, Y. Exosomes: Key players in cancer and potential therapeutic strategy. Signal Transduct. Target. Ther. 2020, 5, 145. [CrossRef] [PubMed]

71. Shelke, G.V.; Yin, Y.; Jang, S.C.; Lasser, C.; Wennmalm, S.; Hoffmann, H.J.; Li, L.; Gho, Y.S.; Nilsson, J.A.; Lotvall, J. Endosomal signalling via exosome surface TGFbeta-1. J. Extracell. Vesicles 2019, 8, 1650458. [CrossRef]

72. Kim, K.; Sohn, Y.J.; Lee, R.; Yoo, H.J.; Kang, J.Y.; Choi, N.; Na, D.; Yeon, J.H. Cancer-Associated Fibroblasts Differentiated by Exosomes Isolated from Cancer Cells Promote Cancer Cell Invasion. Int. J. Mol. Sci. 2020, 21, 8153. [CrossRef]

73. Yang, X.; Li, Y.; Zou, L.; Zhu, Z. Role of Exosomes in Crosstalk Between Cancer-Associated Fibroblasts and Cancer Cells. Front. Oncol. 2019, 9, 356. [CrossRef]

74. Li, W.; Zhang, X.; Wang, J.; Li, M.; Cao, C.; Tan, J.; Ma, D.; Gao, Q. TGFbeta1 in fibroblasts-derived exosomes promotes epithelial-mesenchymal transition of ovarian cancer cells. Oncotarget 2017, 8, 96035-96047. [CrossRef] [PubMed] 
75. Chen, Y.; Zeng, C.; Zhan, Y.; Wang, H.; Jiang, X.; Li, W. Aberrant low expression of p85alpha in stromal fibroblasts promotes breast cancer cell metastasis through exosome-mediated paracrine Wnt10b. Oncogene 2017, 36, 4692-4705. [CrossRef] [PubMed]

76. Bhome, R.; Goh, R.W.; Bullock, M.D.; Pillar, N.; Thirdborough, S.M.; Mellone, M.; Mirnezami, R.; Galea, D.; Veselkov, K.; Gu, Q.; et al. Exosomal microRNAs derived from colorectal cancer-associated fibroblasts: Role in driving cancer progression. Aging 2017, 9, 2666-2694. [CrossRef] [PubMed]

77. Hu, J.L.; Wang, W.; Lan, X.L.; Zeng, Z.C.; Liang, Y.S.; Yan, Y.R.; Song, F.Y.; Wang, F.F.; Zhu, X.H.; Liao, W.J.; et al. CAFs secreted exosomes promote metastasis and chemotherapy resistance by enhancing cell stemness and epithelial-mesenchymal transition in colorectal cancer. Mol. Cancer 2019, 18, 91. [CrossRef]

78. Zhang, Y.; Wang, S.; Lai, Q.; Fang, Y.; Wu, C.; Liu, Y.; Li, Q.; Wang, X.; Gu, C.; Chen, J.; et al. Cancer-associated fibroblasts-derived exosomal miR-17-5p promotes colorectal cancer aggressive phenotype by initiating a RUNX3/MYC/TGF-beta1 positive feedback loop. Cancer Lett. 2020, 491, 22-35. [CrossRef]

79. Matise, L.A.; Palmer, T.D.; Ashby, W.J.; Nashabi, A.; Chytil, A.; Aakre, M.; Pickup, M.W.; Gorska, A.E.; Zijlstra, A.; Moses, H.L. Lack of transforming growth factor-beta signaling promotes collective cancer cell invasion through tumor-stromal crosstalk. Breast Cancer Res. 2012, 14, R98. [CrossRef]

80. Calon, A.; Tauriello, D.V.; Batlle, E. TGF-beta in CAF-mediated tumor growth and metastasis. Semin. Cancer Biol. 2014, 25, 15-22. [CrossRef]

81. Hawinkels, L.J.; Paauwe, M.; Verspaget, H.W.; Wiercinska, E.; van der Zon, J.M.; van der Ploeg, K.; Koelink, P.J.; Lindeman, J.H.; Mesker, W.; ten Dijke, P.; et al. Interaction with colon cancer cells hyperactivates TGF-beta signaling in cancer-associated fibroblasts. Oncogene 2014, 33, 97-107. [CrossRef] [PubMed]

82. Fuyuhiro, Y.; Yashiro, M.; Noda, S.; Matsuoka, J.; Hasegawa, T.; Kato, Y.; Sawada, T.; Hirakawa, K. Cancer-associated orthotopic myofibroblasts stimulates the motility of gastric carcinoma cells. Cancer Sci. 2012, 103, 797-805. [CrossRef] [PubMed]

83. Yu, Y.; Xiao, C.H.; Tan, L.D.; Wang, Q.S.; Li, X.Q.; Feng, Y.M. Cancer-associated fibroblasts induce epithelial-mesenchymal transition of breast cancer cells through paracrine TGF-beta signalling. Br. J. Cancer 2014, 110, 724-732. [CrossRef]

84. Zhuang, J.; Lu, Q.; Shen, B.; Huang, X.; Shen, L.; Zheng, X.; Huang, R.; Yan, J.; Guo, H. TGFbeta1 secreted by cancer-associated fibroblasts induces epithelial-mesenchymal transition of bladder cancer cells through lncRNA-ZEB2NAT. Sci. Rep. 2015, 5, 11924 [CrossRef]

85. Oyanagi, J.; Kojima, N.; Sato, H.; Higashi, S.; Kikuchi, K.; Sakai, K.; Matsumoto, K.; Miyazaki, K. Inhibition of transforming growth factor-beta signaling potentiates tumor cell invasion into collagen matrix induced by fibroblast-derived hepatocyte growth factor. Exp. Cell Res. 2014, 326, 267-279. [CrossRef] [PubMed]

86. Cheng, N.; Chytil, A.; Shyr, Y.; Joly, A.; Moses, H.L. Transforming growth factor-beta signaling-deficient fibroblasts enhance hepatocyte growth factor signaling in mammary carcinoma cells to promote scattering and invasion. Mol. Cancer Res. 2008, 6, 1521-1533. [CrossRef] [PubMed]

87. Grugan, K.D.; Miller, C.G.; Yao, Y.; Michaylira, C.Z.; Ohashi, S.; Klein-Szanto, A.J.; Diehl, J.A.; Herlyn, M.; Han, M.; Nakagawa, H.; et al. Fibroblast-secreted hepatocyte growth factor plays a functional role in esophageal squamous cell carcinoma invasion. Proc. Natl. Acad. Sci. USA 2010, 107, 11026-11031. [CrossRef]

88. Owusu, B.Y.; Galemmo, R.; Janetka, J.; Klampfer, L. Hepatocyte Growth Factor, a Key Tumor-Promoting Factor in the Tumor Microenvironment. Cancers 2017, 9, 35. [CrossRef] [PubMed]

89. Fu, J.; Su, X.; Li, Z.; Deng, L.; Liu, X.; Feng, X.; Peng, J. HGF/c-MET pathway in cancer: From molecular characterization to clinical evidence. Oncogene 2021, 40, 4625-4651. [CrossRef]

90. Spina, A.; De Pasquale, V.; Cerulo, G.; Cocchiaro, P.; Della Morte, R.; Avallone, L.; Pavone, L.M. HGF/c-MET Axis in Tumor Microenvironment and Metastasis Formation. Biomedicines 2015, 3, 71-88. [CrossRef]

91. Jedeszko, C.; Victor, B.C.; Podgorski, I.; Sloane, B.F. Fibroblast hepatocyte growth factor promotes invasion of human mammary ductal carcinoma in situ. Cancer Res. 2009, 69, 9148-9155. [CrossRef]

92. Ding, X.; Ji, J.; Jiang, J.; Cai, Q.; Wang, C.; Shi, M.; Yu, Y.; Zhu, Z.; Zhang, J. HGF-mediated crosstalk between cancer-associated fibroblasts and MET-unamplified gastric cancer cells activates coordinated tumorigenesis and metastasis. Cell Death Dis. 2018, 9, 867. [CrossRef]

93. Joosten, S.P.J.; Spaargaren, M.; Clevers, H.; Pals, S.T. Hepatocyte growth factor/MET and CD44 in colorectal cancer: Partners in tumorigenesis and therapy resistance. Biochim. Biophys. Acta. Rev. Cancer 2020, 1874, 188437. [CrossRef] [PubMed]

94. Vermeulen, L.; De Sousa, E.M.F.; van der Heijden, M.; Cameron, K.; de Jong, J.H.; Borovski, T.; Tuynman, J.B.; Todaro, M.; Merz, C.; Rodermond, H.; et al. Wnt activity defines colon cancer stem cells and is regulated by the microenvironment. Nat. Cell Biol. 2010, 12, 468-476. [CrossRef] [PubMed]

95. Kumari, N.; Dwarakanath, B.S.; Das, A.; Bhatt, A.N. Role of interleukin-6 in cancer progression and therapeutic resistance. Tumour Biol. 2016, 37, 11553-11572. [CrossRef]

96. Karakasheva, T.A.; Lin, E.W.; Tang, Q.; Qiao, E.; Waldron, T.J.; Soni, M.; Klein-Szanto, A.J.; Sahu, V.; Basu, D.; Ohashi, S.; et al. IL-6 Mediates Cross-Talk between Tumor Cells and Activated Fibroblasts in the Tumor Microenvironment. Cancer Res. 2018, 78, 4957-4970. [CrossRef]

97. Wang, L.; Cao, L.; Wang, H.; Liu, B.; Zhang, Q.; Meng, Z.; Wu, X.; Zhou, Q.; Xu, K. Cancer-associated fibroblasts enhance metastatic potential of lung cancer cells through IL-6/STAT3 signaling pathway. Oncotarget 2017, 8, 76116-76128. [CrossRef] 
98. Qin, X.; Yan, M.; Wang, X.; Xu, Q.; Wang, X.; Zhu, X.; Shi, J.; Li, Z.; Zhang, J.; Chen, W. Cancer-associated Fibroblast-derived IL-6 Promotes Head and Neck Cancer Progression via the Osteopontin-NF-kappa B Signaling Pathway. Theranostics 2018, 8, 921-940. [CrossRef] [PubMed]

99. Ji, Z.; Tian, W.; Gao, W.; Zang, R.; Wang, H.; Yang, G. Cancer-Associated Fibroblast-Derived Interleukin-8 Promotes Ovarian Cancer Cell Stemness and Malignancy Through the Notch3-Mediated Signaling. Front. Cell Dev. Biol. 2021, 9, 684505. [CrossRef]

100. Wang, T.; Notta, F.; Navab, R.; Joseph, J.; Ibrahimov, E.; Xu, J.; Zhu, C.Q.; Borgida, A.; Gallinger, S.; Tsao, M.S. Senescent Carcinoma-Associated Fibroblasts Upregulate IL8 to Enhance Prometastatic Phenotypes. Mol. Cancer Res. 2017, 15, 3-14. [CrossRef]

101. Jobe, N.P.; Rosel, D.; Dvorankova, B.; Kodet, O.; Lacina, L.; Mateu, R.; Smetana, K.; Brabek, J. Simultaneous blocking of IL-6 and IL-8 is sufficient to fully inhibit CAF-induced human melanoma cell invasiveness. Histochem. Cell Biol. 2016, 146, 205-217. [CrossRef] [PubMed]

102. Zeng, J.; Tang, Z.H.; Liu, S.; Guo, S.S. Clinicopathological significance of overexpression of interleukin-6 in colorectal cancer. World J. Gastroenterol. 2017, 23, 1780-1786. [CrossRef]

103. Sun, Q.; Shang, Y.; Sun, F.; Dong, X.; Niu, J.; Li, F. Interleukin-6 Promotes Epithelial-Mesenchymal Transition and Cell Invasion through Integrin beta6 Upregulation in Colorectal Cancer. Oxid. Med. Cell Longev. 2020, 2020, 8032187. [CrossRef] [PubMed]

104. Angevin, E.; Tabernero, J.; Elez, E.; Cohen, S.J.; Bahleda, R.; van Laethem, J.L.; Ottensmeier, C.; Lopez-Martin, J.A.; Clive, S.; Joly, F.; et al. A phase I/II, multiple-dose, dose-escalation study of siltuximab, an anti-interleukin-6 monoclonal antibody, in patients with advanced solid tumors. Clin. Cancer Res. 2014, 20, 2192-2204. [CrossRef]

105. Brambilla, L.; Genini, D.; Laurini, E.; Merulla, J.; Perez, L.; Fermeglia, M.; Carbone, G.M.; Pricl, S.; Catapano, C.V. Hitting the right spot: Mechanism of action of OPB-31121, a novel and potent inhibitor of the Signal Transducer and Activator of Transcription 3 (STAT3). Mol. Oncol. 2015, 9, 1194-1206. [CrossRef]

106. Fogelman, D.; Cubillo, A.; Garcia-Alfonso, P.; Miron, M.L.L.; Nemunaitis, J.; Flora, D.; Borg, C.; Mineur, L.; Vieitez, J.M.; Cohn, A.; et al. Randomized, double-blind, phase two study of ruxolitinib plus regorafenib in patients with relapsed/refractory metastatic colorectal cancer. Cancer Med. 2018, 7, 5382-5393. [CrossRef]

107. Lin, Y.; He, Z.; Ye, J.; Liu, Z.; She, X.; Gao, X.; Liang, R. Progress in Understanding the IL-6/STAT3 Pathway in Colorectal Cancer. Onco Targets Ther. 2020, 13, 13023-13032. [CrossRef]

108. Lee, Y.S.; Choi, I.; Ning, Y.; Kim, N.Y.; Khatchadourian, V.; Yang, D.; Chung, H.K.; Choi, D.; LaBonte, M.J.; Ladner, R.D.; et al. Interleukin-8 and its receptor CXCR2 in the tumour microenvironment promote colon cancer growth, progression and metastasis. Br. J. Cancer 2012, 106, 1833-1841. [CrossRef]

109. Najdaghi, S.; Razi, S.; Rezaei, N. An overview of the role of interleukin-8 in colorectal cancer. Cytokine 2020, 135, 155205. [CrossRef]

110. Siena, S.; Sartore-Bianchi, A.; Marsoni, S.; Hurwitz, H.I.; McCall, S.J.; Penault-Llorca, F.; Srock, S.; Bardelli, A.; Trusolino, L. Targeting the human epidermal growth factor receptor 2 (HER2) oncogene in colorectal cancer. Ann. Oncol. 2018, 29, 1108-1119. [CrossRef]

111. Varney, M.L.; Singh, S.; Li, A.; Mayer-Ezell, R.; Bond, R.; Singh, R.K. Small molecule antagonists for CXCR2 and CXCR1 inhibit human colon cancer liver metastases. Cancer Lett. 2011, 300, 180-188. [CrossRef] [PubMed]

112. Wen, S.; Hou, Y.; Fu, L.; Xi, L.; Yang, D.; Zhao, M.; Qin, Y.; Sun, K.; Teng, Y.; Liu, M. Cancer-associated fibroblast (CAF)-derived IL32 promotes breast cancer cell invasion and metastasis via integrin beta3-p38 MAPK signalling. Cancer Lett. 2019, 442, 320-332 [CrossRef]

113. Zhou, Z.; Zhou, Q.; Wu, X.; Xu, S.; Hu, X.; Tao, X.; Li, B.; Peng, J.; Li, D.; Shen, L.; et al. VCAM-1 secreted from cancer-associated fibroblasts enhances the growth and invasion of lung cancer cells through AKT and MAPK signaling. Cancer Lett. 2020, 473, 62-73. [CrossRef]

114. Aizawa, T.; Karasawa, H.; Funayama, R.; Shirota, M.; Suzuki, T.; Maeda, S.; Suzuki, H.; Yamamura, A.; Naitoh, T.; Nakayama, K.; et al. Cancer-associated fibroblasts secrete Wnt2 to promote cancer progression in colorectal cancer. Cancer Med. 2019, 8, 6370-6382. [CrossRef]

115. Kramer, N.; Schmollerl, J.; Unger, C.; Nivarthi, H.; Rudisch, A.; Unterleuthner, D.; Scherzer, M.; Riedl, A.; Artaker, M.; Crncec, I.; et al. Autocrine WNT2 signaling in fibroblasts promotes colorectal cancer progression. Oncogene 2017, 36, 5460-5472. [CrossRef] [PubMed]

116. Calon, A.; Espinet, E.; Palomo-Ponce, S.; Tauriello, D.V.; Iglesias, M.; Cespedes, M.V.; Sevillano, M.; Nadal, C.; Jung, P.; Zhang, X.H.; et al. Dependency of colorectal cancer on a TGF-beta-driven program in stromal cells for metastasis initiation. Cancer Cell 2012, 22, 571-584. [CrossRef] [PubMed]

117. Liu, T.; Han, C.; Wang, S.; Fang, P.; Ma, Z.; Xu, L.; Yin, R. Cancer-associated fibroblasts: An emerging target of anti-cancer immunotherapy. J. Hematol. Oncol. 2019, 12, 86. [CrossRef] [PubMed]

118. Zhang, R.; Qi, F.; Zhao, F.; Li, G.; Shao, S.; Zhang, X.; Yuan, L.; Feng, Y. Cancer-associated fibroblasts enhance tumor-associated macrophages enrichment and suppress NK cells function in colorectal cancer. Cell Death Dis. 2019, 10, 273. [CrossRef] [PubMed]

119. Comito, G.; Giannoni, E.; Segura, C.P.; Barcellos-de-Souza, P.; Raspollini, M.R.; Baroni, G.; Lanciotti, M.; Serni, S.; Chiarugi, P. Cancer-associated fibroblasts and M2-polarized macrophages synergize during prostate carcinoma progression. Oncogene 2014, 33, 2423-2431. [CrossRef] 
120. Takahashi, H.; Sakakura, K.; Kudo, T.; Toyoda, M.; Kaira, K.; Oyama, T.; Chikamatsu, K. Cancer-associated fibroblasts promote an immunosuppressive microenvironment through the induction and accumulation of protumoral macrophages. Oncotarget 2017, 8 , 8633-8647. [CrossRef]

121. Ziani, L.; Safta-Saadoun, T.B.; Gourbeix, J.; Cavalcanti, A.; Robert, C.; Favre, G.; Chouaib, S.; Thiery, J. Melanoma-associated fibroblasts decrease tumor cell susceptibility to NK cell-mediated killing through matrix-metalloproteinases secretion. Oncotarget 2017, 8, 19780-19794. [CrossRef]

122. Ziani, L.; Chouaib, S.; Thiery, J. Alteration of the Antitumor Immune Response by Cancer-Associated Fibroblasts. Front. Immunol. 2018, 9, 414. [CrossRef]

123. Marshall, D.C.; Lyman, S.K.; McCauley, S.; Kovalenko, M.; Spangler, R.; Liu, C.; Lee, M.; O'Sullivan, C.; Barry-Hamilton, V.; Ghermazien, H.; et al. Selective Allosteric Inhibition of MMP9 Is Efficacious in Preclinical Models of Ulcerative Colitis and Colorectal Cancer. PLoS ONE 2015, 10, e0127063. [CrossRef]

124. Olive, K.P.; Jacobetz, M.A.; Davidson, C.J.; Gopinathan, A.; McIntyre, D.; Honess, D.; Madhu, B.; Goldgraben, M.A.; Caldwell, M.E.; Allard, D.; et al. Inhibition of Hedgehog signaling enhances delivery of chemotherapy in a mouse model of pancreatic cancer. Science 2009, 324, 1457-1461. [CrossRef]

125. Riaz, S.K.; Ke, Y.; Wang, F.; Kayani, M.A.; Malik, M.F.A. Influence of SHH/GLI1 axis on EMT mediated migration and invasion of breast cancer cells. Sci. Rep. 2019, 9, 6620. [CrossRef]

126. Mazzocca, A.; Fransvea, E.; Dituri, F.; Lupo, L.; Antonaci, S.; Giannelli, G. Down-regulation of connective tissue growth factor by inhibition of transforming growth factor beta blocks the tumor-stroma cross-talk and tumor progression in hepatocellular carcinoma. Hepatology 2010, 51, 523-534. [CrossRef]

127. Zhang, Q.; Hou, X.; Evans, B.J.; VanBlaricom, J.L.; Weroha, S.J.; Cliby, W.A. LY2157299 Monohydrate, a TGF-betaR1 Inhibitor, Suppresses Tumor Growth and Ascites Development in Ovarian Cancer. Cancers 2018, 10, 260. [CrossRef]

128. Mardhian, D.F.; Storm, G.; Bansal, R.; Prakash, J. Nano-targeted relaxin impairs fibrosis and tumor growth in pancreatic cancer and improves the efficacy of gemcitabine in vivo. J. Control. Release 2018, 290, 1-10. [CrossRef]

129. Yao, Y.; Guo, Q.; Cao, Y.; Qiu, Y.; Tan, R.; Yu, Z.; Zhou, Y.; Lu, N. Artemisinin derivatives inactivate cancer-associated fibroblasts through suppressing TGF-beta signaling in breast cancer. J. Exp. Clin. Cancer Res. 2018, 37, 282. [CrossRef]

130. Froeling, F.E.; Feig, C.; Chelala, C.; Dobson, R.; Mein, C.E.; Tuveson, D.A.; Clevers, H.; Hart, I.R.; Kocher, H.M. Retinoic acid-induced pancreatic stellate cell quiescence reduces paracrine Wnt-beta-catenin signaling to slow tumor progression. Gastroenterology 2011, 141, 1486-1497, 1497.e1-1497.e14. [CrossRef]

131. Han, X.; Li, Y.; Xu, Y.; Zhao, X.; Zhang, Y.; Yang, X.; Wang, Y.; Zhao, R.; Anderson, G.J.; Zhao, Y.; et al. Reversal of pancreatic desmoplasia by re-educating stellate cells with a tumour microenvironment-activated nanosystem. Nat. Commun. 2018, 9, 3390. [CrossRef]

132. Sherman, M.H.; Yu, R.T.; Engle, D.D.; Ding, N.; Atkins, A.R.; Tiriac, H.; Collisson, E.A.; Connor, F.; Van Dyke, T.; Kozlov, S.; et al. Vitamin D receptor-mediated stromal reprogramming suppresses pancreatitis and enhances pancreatic cancer therapy. Cell 2014, 159, 80-93. [CrossRef]

133. Juric, V.; O'Sullivan, C.; Stefanutti, E.; Kovalenko, M.; Greenstein, A.; Barry-Hamilton, V.; Mikaelian, I.; Degenhardt, J.; Yue, P.; Smith, V.; et al. MMP-9 inhibition promotes anti-tumor immunity through disruption of biochemical and physical barriers to T-cell trafficking to tumors. PLoS ONE 2018, 13, e0207255. [CrossRef]

134. Vandenbroucke, R.E.; Libert, C. Is there new hope for therapeutic matrix metalloproteinase inhibition? Nat. Rev. Drug Discov. 2014, 13, 904-927. [CrossRef]

135. Butler, G.S.; Overall, C.M. Updated biological roles for matrix metalloproteinases and new "intracellular" substrates revealed by degradomics. Biochemistry 2009, 48, 10830-10845. [CrossRef]

136. Fields, G.B. The Rebirth of Matrix Metalloproteinase Inhibitors: Moving Beyond the Dogma. Cells 2019, 8, 984. [CrossRef] [PubMed]

137. Hadler-Olsen, E.; Winberg, J.O.; Uhlin-Hansen, L. Matrix metalloproteinases in cancer: Their value as diagnostic and prognostic markers and therapeutic targets. Tumour Biol. 2013, 34, 2041-2051. [CrossRef] [PubMed]

138. Lu, J.T.; Zhao, W.D.; He, W.; Wei, W. Hedgehog signaling pathway mediates invasion and metastasis of hepatocellular carcinoma via ERK pathway. Acta. Pharmacol. Sin. 2012, 33, 691-700. [CrossRef] [PubMed]

139. Steele, N.G.; Biffi, G.; Kemp, S.B.; Zhang, Y.; Drouillard, D.; Syu, L.; Hao, Y.; Oni, T.E.; Brosnan, E.; Elyada, E.; et al. Inhibition of Hedgehog Signaling Alters Fibroblast Composition in Pancreatic Cancer. Clin. Cancer Res. 2021, 27, 2023-2037. [CrossRef]

140. Valenti, G.; Quinn, H.M.; Heynen, G.; Lan, L.; Holland, J.D.; Vogel, R.; Wulf-Goldenberg, A.; Birchmeier, W. Cancer Stem Cells Regulate Cancer-Associated Fibroblasts via Activation of Hedgehog Signaling in Mammary Gland Tumors. Cancer Res. 2017, 77, 2134-2147. [CrossRef]

141. Skoda, A.M.; Simovic, D.; Karin, V.; Kardum, V.; Vranic, S.; Serman, L. The role of the Hedgehog signaling pathway in cancer: A comprehensive review. Bosn. J. Basic Med. Sci. 2018, 18, 8-20. [CrossRef] [PubMed]

142. Szczepny, A.; Rogers, S.; Jayasekara, W.S.N.; Park, K.; McCloy, R.A.; Cochrane, C.R.; Ganju, V.; Cooper, W.A.; Sage, J.; Peacock, C.D.; et al. The role of canonical and non-canonical Hedgehog signaling in tumor progression in a mouse model of small cell lung cancer. Oncogene 2017, 36, 5544-5550. [CrossRef] [PubMed]

143. Gu, D.; Schlotman, K.E.; Xie, J. Deciphering the role of hedgehog signaling in pancreatic cancer. J. Biomed. Res. 2016, 30, 353-360. [CrossRef] 
144. Rajurkar, M.; De Jesus-Monge, W.E.; Driscoll, D.R.; Appleman, V.A.; Huang, H.; Cotton, J.L.; Klimstra, D.S.; Zhu, L.J.; Simin, K.; $\mathrm{Xu}, \mathrm{L}$.; et al. The activity of Gli transcription factors is essential for Kras-induced pancreatic tumorigenesis. Proc. Natl. Acad. Sci. USA 2012, 109, E1038-E1047. [CrossRef] [PubMed]

145. Shi, X.; Young, C.D.; Zhou, H.; Wang, X. Transforming Growth Factor-beta Signaling in Fibrotic Diseases and Cancer-Associated Fibroblasts. Biomolecules 2020, 10, 1666. [CrossRef]

146. Ozdemir, B.C.; Pentcheva-Hoang, T.; Carstens, J.L.; Zheng, X.; Wu, C.C.; Simpson, T.R.; Laklai, H.; Sugimoto, H.; Kahlert, C.; Novitskiy, S.V.; et al. Depletion of carcinoma-associated fibroblasts and fibrosis induces immunosuppression and accelerates pancreas cancer with reduced survival. Cancer Cell 2014, 25, 719-734. [CrossRef] [PubMed]

147. Rhim, A.D.; Oberstein, P.E.; Thomas, D.H.; Mirek, E.T.; Palermo, C.F.; Sastra, S.A.; Dekleva, E.N.; Saunders, T.; Becerra, C.P.; Tattersall, I.W.; et al. Stromal elements act to restrain, rather than support, pancreatic ductal adenocarcinoma. Cancer Cell 2014, 25, 735-747. [CrossRef]

148. Guinney, J.; Dienstmann, R.; Wang, X.; de Reynies, A.; Schlicker, A.; Soneson, C.; Marisa, L.; Roepman, P.; Nyamundanda, G.; Angelino, P.; et al. The consensus molecular subtypes of colorectal cancer. Nat. Med. 2015, 21, 1350-1356. [CrossRef] 